\title{
Salbutamol-induced lactic acidosis in status asthmaticus survivor
}

\author{
Vorakamol Phoophiboon ${ }^{1,2^{*}}$ (D) Parima Singhagowinta ${ }^{3}$, Sangdao Boonkaya ${ }^{3}$ and Thitiwat Sriprasart ${ }^{1}$
}

\begin{abstract}
Background: Salbutamol-induced lactic acidosis is a rare presentation that could manifest in specific clinical context as acute asthmatic attack treatment. An increase of glycolysis pathway leading to pyruvate escalation is the mechanism of hyperlactatemia in $\beta 2$-adrenergic agonist drug.

Case presentation: A 40-year-old man who had poor-controlled asthma, presented with progressive dyspnea with coryza symptom for 6 days. He was intubated and admitted into medical intensive care unit due to deteriorated respiratory symptom. Severe asthmatic attack was diagnosed and approximate 1.5 canisters of salbutamol inhaler was administrated within $24 \mathrm{~h}$ of admission. Initial severe acidosis consisted of acute respiratory acidosis from ventilationperfusion mismatch and acute metabolic acidosis resulting from bronchospasm and hypoxia-related lactic acidosis, respectively. The lactate level was normalized in $6 \mathrm{~h}$ after hypoxemia and ventilation correction. Given the lactate level re-elevated into a peak of $4.6 \mathrm{mmol} / \mathrm{L}$ without signs of tissue hypoxia nor other possible etiologies, the salbutamol toxicity was suspected and the inhaler was discontinued that contributed to rapid lactate clearance. The patient was safely discharged on the 6th day of admission.

Conclusion: The re-elevation of serum lactate in status asthmaticus patient who had been administrated with the vast amount of $\beta 2$-adrenergic agonist should be considered for salbutamol-induced lactic acidosis and promptly discontinued especially when there were no common potentials.
\end{abstract}

Keywords: Salbutamol-induced lactic acidosis, Status asthmaticus, Lactic acidosis, Salbutamol's adverse effect, Case report

\section{Background}

Salbutamol-induced lactic acidosis is an unusual presentation. It could be diagnosed in patients who require the large amount of $\beta 2$-adrenergic agonist in short period as status asthmaticus treatment. Although this salbutamol inhaler is a common drug rescuing airway obstructive problem, there has unexpectedly serious adverse effectlactic acidosis when it is excessively applied. However, there have no definite diagnostic criteria, exclusion of other potential etiologies is essentially required. The

\footnotetext{
*Correspondence: Rakamol@hotmail.com

${ }^{1}$ Division of Pulmonary and Critical Care Medicine, Department of Medicine, Faculty of Medicine, Chulalongkorn University, 1873 Rama 4 road, Pratumwan, Bangkok 10330, Thailand

Full list of author information is available at the end of the article
}

pathophysiology of salbutamol-induced lactic acidosis is an increase of glycolysis pathway resulting in pyruvate and lactate escalation [1-5].

\section{Case presentation}

A 40-year-old man was admitted to medical intensive care unit with acute hypercapnic respiratory failure due to status asthmaticus. His past medical history was poor-controlled asthma that intermittently used only a short-acting bronchodilator for 10 years. He was 12-pack-year smoker which quit over 10 years. He denied alcohol consumption nor recreational drug use. He presented with coryza, myalgia and low grade of fever for 6 days. On the day of admission, he developed difficulty of breathing, respiratory rate of $44 /$ minute. His blood

C The Author(s) 2021. Open Access This article is licensed under a Creative Commons Attribution 4.0 International License, which permits use, sharing, adaptation, distribution and reproduction in any medium or format, as long as you give appropriate credit to the original author(s) and the source, provide a link to the Creative Commons licence, and indicate if changes were made. The images or other third party material in this article are included in the article's Creative Commons licence unless indicated otherwise in a credit line to the material. If material is not included in the article's Creative Commons licence and your intended use is not permitted by statutory regulation or exceeds the permitted use, you will need to obtain permission directly from the copyright holder. To view a copy of this licence, visit http://creativecommons.org/licenses/by/4.0/. The Creative Commons Public Domain Dedication waiver (http://creativeco mmons.org/publicdomain/zero/1.0/) applies to the data made available in this article, unless otherwise stated in a credit line to the data. 
pressure was 184/122 $\mathrm{mm} \mathrm{Hg}$ and tachycardia of 120 / minute. An initial oxygen saturation was $85 \%$ at room air. On examination, he had poor air-entry with biphasic wheezing throughout the lung's field. After intubation, he was deeply sedated and paralyzed in order to being controlled with a proper setting of mechanical ventilation. Arterial blood gas revealed acute respiratory acidosis with $\mathrm{PH}$ of $6.98, \mathrm{PaO}_{2}$ of $90 \mathrm{~mm} \mathrm{Hg}$ (under fraction of inspired oxygen- $\mathrm{FiO}_{2}$;0.6) and $\mathrm{PaCO}_{2}$ of $119.5 \mathrm{~mm}$ $\mathrm{Hg}$. The chest radiograph and initial serum investigations were unremarkable. Nasal swab for respiratory viral test was positive for Enterovirus/Rhinovirus. The essential investigations and dose of sedative drugs are shown in Table 1. During the admission, patient's mean arterial pressure was over $65 \mathrm{mmHg}$ without inotrope's support. The salbutamol inhaler $(100 \mathrm{mcg} / \mathrm{puff})$ was administrated via ventilator's inspiratory circuit, 4-8 puffs every 15-30 min. Furthermore, salmeterol/fluticasone propionate MDI $(25 \mathrm{mcg} / 250 \mathrm{mcg}) 4$ inhalations every $12 \mathrm{~h}$ and four inhalations of tiotropium bromide soft mist inhaler $(2.5 \mathrm{mcg})$ were used as inhaled controllers. Not only intravenous steroid was used for exacerbation regimen, but two grams of magnesium sulphate infusion was also given. Ceftriazone, azithromycin and oseltamivir were empirically started and discontinued when nasal swab, sputum culture and blood cultures revealed none of other co-infections. We did not use an aminophylline nor inhaled anesthetic agent due to unavailability. The ventilator setting was volume-controlled mode, $5 \mathrm{ml} / \mathrm{kg}$ of ideal body weight, $5 \mathrm{~cm} \mathrm{H}_{2} \mathrm{O}$ of positive end expired pressure (PEEP), 0.6 of $\mathrm{FiO}_{2}$ and $60-100 \mathrm{~L} /$ min of decelerating flow. After $6 \mathrm{~h}$ of treatment, patient's ventilation and oxygenation showed significant improvement contributing to lactate normalization (from 4.4 to $0.7 \mathrm{mmol} / \mathrm{L}$ ). However, at $24 \mathrm{~h}$ of admission, his lactate level had re-elevated to a peak of $4.6 \mathrm{mmol} / \mathrm{L}$ contrary to the improvement of $\mathrm{PaO}_{2}, \mathrm{PaCO}_{2}$, patient's symptoms and mechanical ventilator's setting. There was a minimal rising of creatinine, potassium and creatinine phosphokinase (CPK) which was less likely to make a diagnosis of rhabdomyolysis. Furthermore, none of liver function test, urine analysis, lipid profiles and electrocardiogram's finding had illustrated abnormality. Four and a half Litres of lactated Ringer's solution were infusing for fluid resuscitation and maintenance during the first $48 \mathrm{~h}$. The urine output throughout $48 \mathrm{~h}$ of admission was $45-180 \mathrm{ml} / \mathrm{h}$ with positive accumulative balance of $3.2 \mathrm{~L}$. The salbutamol inhaler was discontinued while patient's

Table 1 Laboratory investigations, ventilator settings and sedative drugs

\begin{tabular}{|c|c|c|c|c|c|c|c|}
\hline & Oh & $6 \mathrm{~h}$ & $12 \mathrm{~h}$ & $24 \mathrm{~h}$ & $32 \mathrm{~h}$ & $48 \mathrm{~h}$ & $54 \mathrm{~h}$ \\
\hline \multicolumn{8}{|l|}{ Arterial blood gas } \\
\hline $\mathrm{PH}$ & 6.98 & 7.29 & 7.24 & 7.26 & 7.42 & 7.43 & 7.45 \\
\hline $\mathrm{PaO}_{2}(\mathrm{~mm} \mathrm{Hg})$ & 90 & 91.9 & 119.2 & 95.6 & 61.9 & 79.2 & 76 \\
\hline $\mathrm{PaCO}_{2}(\mathrm{~mm} \mathrm{Hg})$ & 119.5 & 55.6 & 48 & 52 & 44 & 42.8 & 38.4 \\
\hline $\mathrm{HCO}_{3}(\mathrm{mmol} / \mathrm{L})$ & 20 & 22 & 16 & 12 & 22 & 25 & 25 \\
\hline Serum lactate (mmol/L) & 4.4 & 0.7 & 2.3 & 4.6 & 1.3 & 0.9 & 0.7 \\
\hline Creatinine phosphokinase $(U / L)$ & - & - & 1,877 & 2,007 & - & 1,454 & 880 \\
\hline Creatinine (mg/dL) & 0.87 & - & 1.16 & - & - & 1.06 & 0.92 \\
\hline Potassium (mmol/L) & 3.8 & 5.3 & 5.4 & 4.4 & 4 & 3.9 & 4.2 \\
\hline \multicolumn{8}{|l|}{ Ventilator settings } \\
\hline Mode & VCV & VCV & VCV & VCV & VCV & PSV & PSV \\
\hline Tidal volume (ml/kg) & 5.5 & 5.5 & 4.3 & 4.3 & 6 & $6-7$ & $6-7$ \\
\hline Tidal volume (ml) & $380-390$ & $380-390$ & 300 & 300 & 420 & $420-490$ & $420-490$ \\
\hline $\operatorname{PEEP}\left(\mathrm{cm} \mathrm{H}_{2} \mathrm{O}\right)$ & 5 & 5 & 5 & 5 & 5 & 5 & 5 \\
\hline Respiratory rate (/min) & $20-25$ & $20-25$ & 14 & 14 & 14 & 14 & 14 \\
\hline Flow (L/min) & 60 & 60 & $70-100$ & $70-100$ & 60 & - & - \\
\hline $\mathrm{FiO}_{2}$ & 0.6 & 0.4 & 0.4 & 0.4 & 0.3 & 0.3 & 0.3 \\
\hline \multicolumn{8}{|l|}{ Drugs } \\
\hline Propofol (mg/h) & - & 200 & 100 & 100 & 60 & off & - \\
\hline Fentanyl (mcg/h) & 50 & 80 & 50 & 80 & 80 & 80 & 50 \\
\hline Midazolam (mg/h) & 4 & 5 & 6 & 6 & 4 & off & - \\
\hline Cisatracurium (mcg/kg/min) & - & 2.2 & 2.2 & off & - & - & - \\
\hline Salbutamol inhaler (puffs) & N/A & N/A & $\mathrm{N} / \mathrm{A}$ & Total $315 \rightarrow$ off & - & - & - \\
\hline
\end{tabular}


clinical status improved, a total dose of salbutamol was $31,500 \mathrm{mcg}$ (315 puffs). The lactate level had rapidly decreased into normal range within $12 \mathrm{~h}$ of discontinuation and the patient was extubated safely at day 5 of the admission.

\section{Discussion and conclusion}

Status asthmaticus is a severe stage of asthma exacerbation which required multimodalities of treatment such as high dose of bronchodilators, intubation with high mechanical ventilator's setting and deep sedation. To effectively manage peripheral airway obstruction, salbutamol inhaler is a drug of choice for ameliorating bronchospasm but it remains uncertainty of maximum dose especially using through mechanical ventilator. The initial reduction of lactate level in the first $6 \mathrm{~h}$ as a result of improvement of hypoxemia and bronchospasm. In arterial blood gas analysis, the initial presentation was a combination of acute respiratory acidosis and metabolic acidosis which respiratory cause was a major contribution. When the bronchospasm had been improved, the overall $\mathrm{PH}$ was rising. However, the recovery of airway disease was not complete, in addition to the re-worsening of lactic acidosis predisposing to ongoing acidosis. Our case demonstrated an explicit point of lactate level's rebound after normalization, there were none of other potential etiologies of lactate's re-elevation such as persistent hypotension, uncontrolled viral infection, hospital-acquired infection, abnormal lactate clearance relating to liver or renal dysfunction. The medicationinduced lactatemia as type B (non-hypoperfusion cause) should be considered in this case which is reported in several mechanisms of lactate production [5-7] However, the potential drugs in our case were salbutamol inhaler and propofol infusion, which propofol is unlikely presented without propofol infusion syndrome (PRIS). PRIS generally consists of rhadomyolysis, abnormal lipid profiles and cardiac dysfunction, the uncoupling oxidative phosphorylation is the mechanism of PRIS-related hyperlactatemia [8-10]. Furthermore, lactated Ringer's solution does not seem to increase circulating lactate concentration unless infusing large volumes $(180 \mathrm{ml} /$ $\mathrm{kg} / \mathrm{h})[11,12]$.

Given there are no diagnostic criteria of salbutamolinduced lactic acidosis, drug levels nor determined dose, deliberate clinical evaluation and exclusion are essential in this context. There was a retrospective cohort that reported the $1200 \mathrm{mcg}$ of albuterol causing lactic acidosis in a couple hours whereas our case was used in the higher amount [13]. As a systematic review, the lactate level of drug-induced hyperlactatemia was reported in wide range and 1.9 days was a median time of lactate clearance [4]. In our case illustrated the suspected salbutamol-induced lactic acidosis that showed the using dose $(31,500 \mathrm{mcg})$, the duration of onset (within $24 \mathrm{~h})$, the peak of drug-induced lactate $(4.6 \mathrm{mmol} / \mathrm{L})$ and the clearance of drug-induced lactate $(8 \mathrm{~h})$. This observational information may be useful for guiding diagnosis. After salbutamol inhaler discontinuation, the lactate level decreased rapidly, so salbutamol-induced lactic acidosis was diagnosed. Although there are some mechanisms reported that glucocorticoid enhances the efficacy of $\beta 2$-adrenergic agent which may or may not worsen lactic acidosis, the benefit of glucocorticoid in asthmatic attack treatment is obvious [14]. For further study, the implementation of either drug toxicity level or minimum accumulative amount to confirm the diagnosis is essentially required.

Salbutamol-induced lactic acidosis is a rare presentation, potentially occurred when severe asthmatic attack diagnosed. The increase of glycolysis and pyruvate production without poor perfusion state is the main mechanism of lactate production in $\beta 2$-adrenergic agents. Exclusion of other potential etiologies of lactic acidosis is necessary, but salbutamol-induced lactic acidosis should also be aware in this context.

\section{Abbreviations}

VCV: Volume controlled ventilation; PSV: Pressure support ventilation; PEEP: Positive end-expiratory pressure; $\mathrm{FiO}_{2}$ : Fraction of inspired oxygen; CPK: Creatinine phosphokinase; PRIS: Propofol infusion syndrome.

\section{Acknowledgements}

We would like to thank Division of Pulmonary and Critical Care Medicine, Department of Medicine, Chulalongkorn University, Bangkok, Thailand and Medical Intensive Care II unit.

\section{Authors' contributions}

VP and TS designed and drafted this manuscript. SB and PS researched related articles, drafted and revised manuscript. All authors interpreted and revised the final approval of the manuscript to be published. All authors contributed equally in the preparation of this manuscript.

\section{Funding}

This case report did not receive any specific grant from funding agencies in the public, commercial, or not-for-profit sectors.

\section{Availability of data and materials}

All data are available in the manuscript [and its supplementary information files].

\section{Ethics approval and consent to participate}

Not applicable.

\section{Consent for publication}

Written informed consent was obtained from the patient for publication of this case report and any accompanying images. A copy of the written consent is available for review by the Editor of this journal.

\section{Competing Interests}

The authors declare that they have no competing interests.

\section{Author details}

1 Division of Pulmonary and Critical Care Medicine, Department of Medicine, Faculty of Medicine, Chulalongkorn University, 1873 Rama 4 road, Pratumwan, 
Bangkok 10330, Thailand. ${ }^{2}$ Excellence Center for Critical Care Medicine, King Chulalongkorn Memorial Hospital, Thai Red Cross Society, Bangkok, Thailand. ${ }^{3}$ Department of Medicine, Faculty of Medicine, Chulalongkorn University, Bangkok, Thailand.

Received: 4 November 2020 Accepted: 5 January 2021

Published online: 12 January 2021

\section{References}

1. Kraut JA, Madias NE. Lactic acidosis. N Engl J Med. 2014;371(24):2309-19.

2. Pearmain L, Gupta R, Bright-Thomas RJ. Lessons of the month 1: salbutamol induced lactic acidosis: clinically recognised but often forgotten. Clin Med (Lond). 2020;20(1):101-4

3. Dodda VR, Spiro P. Can albuterol be blamed for lactic acidosis? Respir Care. 2012;57(12):2115-8.

4. Smith ZR, Horng M, Rech MA. Medication-induced hyperlactatemia and lactic acidosis: a systematic review of the literature. Pharmacotherapy. 2019;39(9):946-63.

5. Seheult J, Fitzpatrick G, Boran G. Lactic acidosis: an update. Clin Chem Lab Med (CCLM). 2017:55(3):322-33.

6. Hernandez G, Bellomo R, Bakker J. The ten pitfalls of lactate clearance in sepsis. Intensive Care Med. 2019:45(1):82-5.

7. Di Mauro FM, Schoeffler GL. Point of care measurement of lactate. Top Compan Anim Med. 2016:31(1):35-43.
8. Mirrakhimov AE, Voore P, Halytskyy O, Khan M, Ali AM. Propofol infusion syndrome in adults: a clinical update. Crit Care Res Pract. 2015:2015:260385

9. Hemphill S, McMenamin L, Bellamy MC, Hopkins PM. Propofol infusion syndrome: a structured literature review and analysis of published case reports. Br J Anaesth. 2019;122(4):448-59.

10. Kam PCA, Cardone D. Propofol infusion syndrome. Anaesthesia. 2007;62(7):690-701.

11. Didwania A, Miller J, Kassel D, Jackson EV Jr, Chernow B. Effect of intravenous lactated Ringer's solution infusion on the circulating lactate concentration: Part 3. Results of a prospective, randomized, double-blind, placebo-controlled trial. Crit Care Med. 1997;25(11):1851-4.

12. Boysen SR, Dorval P. Effects of rapid intravenous $100 \%$ L-isomer lactated Ringer's administration on plasma lactate concentrations in healthy dogs. J Vet Emerg Crit Care (San Antonio). 2014;24(5):571-7.

13. Rodrigo GJ, Rodrigo C. Elevated plasma lactate level associated with high dose inhaled albuterol therapy in acute severe asthma. Emerg Med J. 2005;22(6):404-8.

14. Braden GL, Johnston SS, Germain MJ, Fitzgibbons JP, Dawson JA. Lactic acidosis associated with the therapy of acute bronchospasm. N Engl J Med. 1985;313(14):890-1.

\section{Publisher's Note}

Springer Nature remains neutral with regard to jurisdictional claims in published maps and institutional affiliations.
Ready to submit your research? Choose BMC and benefit from:

- fast, convenient online submission

- thorough peer review by experienced researchers in your field

- rapid publication on acceptance

- support for research data, including large and complex data types

- gold Open Access which fosters wider collaboration and increased citations

- maximum visibility for your research: over $100 \mathrm{M}$ website views per year

At BMC, research is always in progress.

Learn more biomedcentral.com/submissions 